\title{
Energy and protein intake in the Colombian population: results of the 2015 ENSIN population survey
}

\author{
Oscar F. Herrán ${ }^{1} *$ (D), Edna M. Gamboa-Delgado ${ }^{1}$ and María Del Pilar Zea ${ }^{2}$ \\ ${ }^{1}$ Universidad Industrial de Santander, Carrera 32 No. 29-31, 680002, Bucaramanga, Santander, Colombia \\ ${ }^{2}$ Universidad Javeriana de Cali, Facultad de Ciencias de la Salud, Cali, Valle, Colombia
}

(Received 26 September 2020 - Final revision received 23 December 2020 - Accepted 12 January 2021)

Journal of Nutritional Science (2021), vol. 10, e11, page 1 of 10

doi:10.1017/jns.2021.2

Abstract

The present study was aimed at (1) the differences between current weight $v$. ideal weight, (2) total energy intake and comparing it with required energy (Rkeer), (3) absolute protein intake in $\mathrm{g} / \mathrm{kg}$ per $\mathrm{d}$ and $\mathrm{g} / 1000$ calories, (4) how energy and protein intake relate to the nutritional status of the subjects in terms of overall overweight (OEW) [overweight + obesity] and conservative overweight (CEW) [obesity] and (5) the contribution (\%) of protein to total energy intake based on the acceptable macronutrient distribution range (AMDR). A dietary study was carried out in Colombia with 29259 subjects between 1 and 64 years of age, based on cross-sectional data collected in 2015 by a 24-h dietary recall (24HR) administered as part of the National Nutrition Survey. Energy and protein intake did not differ by nutritional status. In the general population, energy intake was $2117 \mathrm{kcal} / \mathrm{d}$ (95\% CI 1969, 2264). The total protein intake was $64.3 \mathrm{~g} / \mathrm{d}(95 \%$ CI 61·4, 67.3). Adequate energy intake ranged from 90 to $100 \%$, except for the 1-4-year-old group, which ranged from 144 to $155 \%$. Protein intake was $1.64 \mathrm{~g} / \mathrm{kg}$ per d (95\% CI 1.53, 1.75). The mean AMDR for protein to total energy intake was $13 \cdot 3 \%(95 \%$ CI $12 \cdot 9$, 13.7). Excess weight began during the first 4 years of age. In conclusion, it is worth reviewing and updating energy and protein intake recommendations and dietary guidelines for the Colombian population and designing and modifying public policy.

Key words: Nutritional surveys: Dietary proteins: Energy intake: Diet: Body weight: Colombia

\section{Introduction}

In Colombia, South America, demographic, economic and epidemiological transitions have been accompanied by two other simultaneous transitions $^{(1)}$ : (1) nutritional, where overweight is more prevalent than obesity ${ }^{(2)}$, and (2) alimentary $^{(3)}$, where the traditional dietary pattern may be a protective factor against developing overweight and obesity, which are mediators of cardiovascular disease and cancer ${ }^{(3-5)}$.

Given the limited or non-existent scientific evidence at the local level in Colombia, public policies on food insecurity, nutritional deficiencies and nutritional and dietary status have followed approaches used in other cultural and socioeconomic contexts. In the general population, individual dietary practices stem from a combination of various aspects that involve the context in which people live, such as personal or individual factors, as well as external factors in the food environment, including physical, economic, sociocultural and political $^{(6)}$. The explanations of these practices have lacked epidemiological thought, for example, multicausality.

Overweight in Colombian adults rose from 45.9\% in 2005 to $51.2 \%$ in 2010 and $56.5 \%$ in 2015 , while obesity increased from 13.7 to $16 \cdot 5 \%$ and $18.7 \%$ over the same period ${ }^{(7)}$. Nevertheless, adherence to physical activity recommendations also increased, from $19.9 \%$ in 2010 to $23.5 \%$ in $2015^{(7)}$, while the frequency of snack consumption decreased $9.9 \%$ for children and $13 \cdot 3 \%$ for adults between 2010 and $2015^{(8)}$.

Food and nutrition policies impact the environment, the economy and other public policies; one example is a recommendation to update the Dietary Guidelines for

* Corresponding author: Oscar F. Herrán, fax +57-76323215, email herran@uis.edu.co; oscar.herran@gmail.com 
Americans ${ }^{(9)}$. Both the amount and quality of protein consumption have been of interest due to their association with serum iron levels, cholesterol, saturated fat, the development of chronic illness, and more recently, with the carbon footprint. The impact that diet has on different environments (economic, social, cultural, industrial and technological, among others) is a complex issue and a new field of formal research. The United States Department of Agriculture proposes six categories that have an environmental impact and political importance: (1) global warming potential, (2) land use, (3) water depletion, (4) marine eutrophication, (5) availability of potable water and (6) respiratory particulate or organic material $^{(9)}$.

In terms of the Americas, 24-h dietary recall questionnaires (24HR) have been used to estimate dietary intake in Canada (2004), Colombia (2005, 2015), Argentina (2005), Peru (2006), Mexico (2006, 2012) and the United States (19992016). While no significant changes in energy and protein intake were found between survey years in Mexico ${ }^{(10,11)}$, an increase was found in the U.S ${ }^{(12)}$.

In Colombia, the 2005 ENSIN $^{(13)}$ and the Energy and Nutrients Intake Recommendations (RIEN in Spanish) ${ }^{(14)}$ indicate a deficiency of $36-50 \cdot 1 \%$ in usual protein intake. Colombia updated the RIEN in 2016 based on the epidemiological and nutritional profile of the Colombia population. This guideline sets an acceptable macronutrient distribution range (AMDR) of $10-20 \%$ for protein for the different population groups and suggests a minimum of $15 \%$ in order to meet the average estimated micronutrient requirement ${ }^{(14)}$.

The present study was aimed at determining (1) the differences between current weight $v$. ideal weight, (2) total energy intake and comparing it with required energy (Rkeer), (3) absolute protein intake in $\mathrm{g} / \mathrm{kg}$ per $\mathrm{d}$ and $\mathrm{g} / 1000$ calories, (4) how energy and protein intake relate to the nutritional status of the subjects in terms of overall overweight (OEW) [overweight + obesity] and conservative overweight (CEW) [obesity] and (5) the contribution $(\%)$ of protein to total energy intake based on the AMDR.

\section{Materials and methods}

Colombia (South America) is a middle-income country with large socio-economic inequalities. Three national nutrition surveys (ENSIN in Spanish [Encuestas Nacionales de la Situación Nutricional]) were conducted between 2005 and 2015 using a cross-sectional design. The analysis was based on data on energy $(\mathrm{kcal} / \mathrm{d})$ and protein $(\mathrm{g} / \mathrm{d})$ intake obtained from a 24HR conducted as part of the 2015 ENSIN, which was a nationally representative survey with a complex and multistage sample design. The methodological details have previously been published ${ }^{(15)}$.

\section{Population and sample}

The 2015 ENSIN surveyed 44202 urban and rural households and interviewed 151343 subjects. The sample included 4739 segments located in 295 municipalities in the country's 32 departments and in Bogota, Colombia's capital. Various probabilistic subsamples were calculated to study specific topics, including nutrient intake, nutritional practices of interest and breast-feeding, among others. The 2015 ENSIN sample was based on the Master Household Sample for Health Studies, of the National System of Health Population Studies and Surveys, developed and implemented in 2013 by the Ministry of Health and Social Protection (7). Subjects were selected with various sampling methods, including probability, cluster, stratified and multistage. The primary sampling unit was the department, the secondary was the municipalities and the tertiary was the housing of the subjects. The subsample that constituted the 24HR included 34099 subjects between 0 and 64 years old, 4589 of whom filled out a second 24HR. Excluded from the 34099 were children between 0 and 1 year of age ( $n$ 1770), pregnant women ( $n$ 2589) and those without data on weight, height or both ( $n$ 481). The $24 \mathrm{HR}$ response rate was $84 \%$. The final sample that was analysed included 29259 subjects.

\section{Source of data}

Trained personnel administered the questionnaire to heads of household to obtain information on sociodemographics, food security and household wealth. Moreover, nutritionists administered the 24HR using the Automated Multiple-Pass Method (AMPM) developed in 1999 by the United States Department of Agriculture (USDA) ${ }^{(15,16)}$. For children under 12 years old, consumption information was supplied by the person who was responsible for having prepared and served their food the previous day and/or who accompanied the child while eating. For adolescents between 12 and 14 years old and adults 60 years or older, a rapid memory test was conducted before administering the 24HR, which included 4 of the 10 items proposed by Hodkinson in 1972 to identify dementia in elderly patients ${ }^{(17)}$. When one of the four questions was not adequately answered by the subject, the information was provided by the caregiver or the person responsible for feeding the child. Anthropometric measurements were taken by trained interviewers using standardised techniques and calibrated equipment. Size was determined with stadiometers (Shorr Productions LCC, Olney, MD, USA) to the nearest millimetre. SECA scales (model 874) were used to determine weight to the nearest $100 \mathrm{~g}$.

The main outcome variables were OEW, CEW and energy $(\mathrm{kcal} / \mathrm{d})$ and protein $(\mathrm{g} / \mathrm{d})$ intake. Eleven covariables were also studied: sex, age, weight circumference, adherence to weekly physical activity goals, number of household members, household food security, wealth index, educational level of the head of household, ethnicity, degree of urbanism and geographic region.

\section{Nutritional status}

Values for weight, size and sex were converted to $Z$ scores based on growth references by the World Health Organization (WHO) ${ }^{(17,18)}$. For children up to 17 years old, OEW was based on body mass index for age (BMI/A) and $Z$-score $>1$, and CEW was based on $Z$-score $>2$. For adults, 
overweight was defined as $\geq 25 \mathrm{BMI}<30\left(\mathrm{~kg} / \mathrm{mt}^{2}\right)$, obesity as $\mathrm{BMI} \geq 30$, OEW $=$ overweight + obesity and $\mathrm{CEW}=$ obesity. In addition, for each individual with low or excess weight, the 2015 ENSIN estimated 'adequate weight' based on its own data using two predictive equations (linear regressions): one for subjects between 1 and 17 years old and another for those between 18 and 64 years old. The equations included data on the sex, weight, size and age of the individuals with normal nutritional status for the age group ${ }^{(19)}$.

\section{Energy and protein intake}

After rigorous quality control, the $24 \mathrm{HR}$ were converted to nutrients based on a food composition database specifically designed for the 2015 ENSIN. This database contains 2703 items and 9 nutritional variables. In addition, following recommendations by the $2001 \mathrm{FAO} / \mathrm{WHO} / \mathrm{UNU}$ Expert Consultation $^{(20)}$, the Estimated Energy Requirement (EER) was calculated for each individual based on RIEN $^{(14)}$. Energy $(\mathrm{kcal} / \mathrm{d})$ and protein $(\mathrm{g} / \mathrm{d})$ intake were reported in absolute terms based on the first 24HR. Protein intake was reported as nutrient density in grams per 1000 calories $(\mathrm{g} /$ $1000)$ and as the ratio of absolute protein intake/day (g/d) to adequate weight (Rprotein). Lastly, the ratio of absolute kcal intake/day to EER was calculated and expressed as requirement units (Rkeer) or adequacy (\%EER).

\section{Adherence to weekly physical activity goals}

The 2015 ENSIN calculated this potential confounder based on minimum adherence per week, using different methods for different age groups ${ }^{(15)}$. For children under 6 years old, adherence was defined as $180 \mathrm{~min}$ or more of play per day over the prior $7 \mathrm{~d}$, according to C-MAFYCS ${ }^{(21,22)}$. For adolescents between 6 and 17 years old, adherence to physical activity recommendations was defined as 60 or more $\mathrm{min} / \mathrm{d}$ of moderate or vigorous physical activity, according to the Youth Risk Behavior Surveillance System ${ }^{(23)}$. Adherence for adults was defined as at least $150 \mathrm{~min}$ of moderate or 75 min of vigorous aerobic physical activity/week, according to the International Physical Activity Questionnaire (IPAQ) developed by the $\mathrm{WHO}^{(24)}$.

Large waist circumference was defined as $\geq 90 \mathrm{~cm}$ for men and $\geq 80 \mathrm{~cm}$ for women. The degree of urbanism was categorised as urban and rural based on the population density reported by the 2015 ENSIN $^{(15)}$. Household food security was determined with the Latin American and Caribbean Food Security Scale (ELCSA in Spanish) ${ }^{(25)}$. Wealth level was designated based on the index designed for the international demographics and health survey ${ }^{(26)}$, with the highest values representing the wealthiest subjects.

\section{Statistical analysis}

All analyses were performed using the routines for complex sampling designs in Stata software version $14.1^{(27)}$. The statistical analysis was aimed at (1) describing socio-demographic characteristics, (2) for each category of covariates, describing the energy and protein intake of the subjects with prevalences $(\%)$ or averages, and presenting each one with its standard error (SE) or $95 \%$ confidence interval ( $95 \%$ CI), (3) determining the prevalence ratio of protein intake to adequate weight $(\mathrm{g} / \mathrm{kg}$ per $\mathrm{d})$ in subjects with and without excess weight and (4) determining the average prevalence ratio of energy intake to energy required in subjects with and without excess weight.

Multiple linear regressions were performed to obtain adjusted differences in protein and energy intake between subjects with and without excess weight, and with and without conservative excess weight, with their different expressions for each category of covariates. To this end, a new term was created with the result of the cross product of intake and each category of covariates (interaction). The adjusted differences and their respective $95 \%$ CIs incorporated the complex sample design, and the multiple regression model included the covariates sex, age, adherence to physical activity, household size, household food insecurity, wealth index, ethnicity, education level of head of household, geographic area and region.

\section{Ethics approval and consent to participate}

All analyses were performed in accordance with the principles of the Helsinki Declaration ${ }^{(28)}$. The databases used are available to the public. This research is classified as 'without risk' according to Resolution 8430 of the Colombian Ministry of Health $(1993)^{(29)}$. Since this is a secondary analysis of population studies with anonymised data, no authorisation was required from the Health Research Ethics Committee of the Industrial University of Santander.

\section{Results}

A total of 29259 subjects were studied, $48.8 \%$ of which were men. The OEW of the population was $28 \cdot 7 \%: 27 \cdot 6 \%$ for men and $30 \cdot 0 \%$ for women $(P=0 \cdot 123)$. Nine percent $(9 \cdot 0$ $\%)$ of the population had CEW: $8.7 \%$ of men and $9.2 \%$ of women $(P=0.506)$. A total of $25.8 \%$ of subjects met the physical activity recommendations, $37.5 \%$ of households were food secure and $77.3 \%$ of subjects lived in urban regions. Table 1 presents the remaining socio-demographic characteristics of the subjects studied, according to excess weight categories.

\section{Adequate and current weight}

The average adequate weight was $13 \cdot 6 \mathrm{~kg}(95 \%$ CI 13.0, 14.2) in the 1-4-year-old group, $26 \mathrm{~kg}(95 \%$ CI $23 \cdot 5,28 \cdot 5)$ in the 5-12-year-old group, $50 \cdot 6 \mathrm{~kg}(95 \% \mathrm{CI} 49 \cdot 2,52 \cdot 0)$ in the 13-17-year-old group, $59 \cdot 1 \mathrm{~kg}(95 \%$ CI $58 \cdot 4,59 \cdot 8)$ in the 18-26-year-old group, $59 \cdot 8 \mathrm{~kg}(95 \%$ CI $58 \cdot 8,60 \cdot 7)$ in the 27-49-year-old group and 58.0 (95\% CI 56.7, 59.3) in the 50-64-year-old group $(P<0 \cdot 0001)$. The mean differences between current and adequate weight were $0.5 \mathrm{~kg}$ (95 $\% \mathrm{CI}-1 \cdot 8,2 \cdot 9)$ in the 1-4-year-old group, $1 \cdot 8(-5 \cdot 9,9 \cdot 6)$ in the $5-12$-year-old group, $2 \cdot 2 \mathrm{~kg}(95 \% \mathrm{CI}-11 \cdot 7,16 \cdot 1)$ in the 13-17-year-old group, $4.5 \mathrm{~kg}$ (95\% CI $-15 \cdot 5,24 \cdot 4)$ in the 18-26-year-old group, $10 \cdot 4 \mathrm{~kg}(95 \% \mathrm{CI}-14 \cdot 6,35 \cdot 3)$ in the 27-49-year-old group and $11.3 \mathrm{~kg}(95 \% \mathrm{CI}-12 \cdot 1$, 34.7 ) in the 50-64-year-old group (linear trend test; $P<$ 0.0001). Excess weight began during the first 4 years, after 
Table 1. Characteristics of the population studied

\begin{tabular}{|c|c|c|c|c|c|c|c|c|}
\hline \multirow[b]{2}{*}{ Variable } & \multicolumn{2}{|c|}{ Total [29 259] ${ }^{*}$} & \multicolumn{2}{|c|}{$\begin{array}{l}\text { Non-overall excess } \\
\text { weight }^{\text {a }}[20844]\end{array}$} & \multicolumn{2}{|c|}{$\begin{array}{l}\text { Overall excess } \\
\text { weight }^{\mathrm{b}}[8415]\end{array}$} & \multicolumn{2}{|c|}{$\begin{array}{l}\text { Conservative } \\
\text { overweight }^{c} \text { [2631] }\end{array}$} \\
\hline & $n^{\dagger}$ & $\%^{\ddagger}$ & $n^{\dagger}$ & $\%^{\ddagger}$ & $n^{\dagger}$ & $\%^{\ddagger}$ & $n^{\dagger}$ & $\%^{\ddagger}$ \\
\hline \multicolumn{9}{|l|}{ Sex } \\
\hline Male & 14302 & $50 \cdot 0$ & 10240 & $50 \cdot 7$ & 4062 & $48 \cdot 1$ & 1264 & 48.5 \\
\hline Female & 14937 & $50 \cdot 0$ & 10604 & $49 \cdot 3$ & 4353 & $51 \cdot 9$ & 1367 & $51 \cdot 5$ \\
\hline \multicolumn{9}{|l|}{ Age (years) } \\
\hline $1-4$ & 6294 & 8.9 & 4514 & 8.8 & 1780 & $9 \cdot 4$ & 568 & $9 \cdot 6$ \\
\hline $5-12$ & 6175 & $20 \cdot 1$ & 4424 & $19 \cdot 8$ & 1751 & $20 \cdot 8$ & 550 & $21 \cdot 6$ \\
\hline $13-17$ & 6968 & $11 \cdot 0$ & 5026 & $11 \cdot 2$ & 1942 & $10 \cdot 6$ & 602 & $10 \cdot 1$ \\
\hline $18-26$ & 1987 & $13 \cdot 6$ & 1413 & 13.9 & 574 & $13 \cdot 0$ & 185 & $13 \cdot 0$ \\
\hline $27-49$ & 4945 & $32 \cdot 3$ & 3462 & $32 \cdot 7$ & 1483 & $31 \cdot 1$ & 438 & $27 \cdot 8$ \\
\hline $50-64$ & 2427 & $14 \cdot 1$ & 1677 & $13 \cdot 6$ & 750 & $15 \cdot 3$ & 247 & $17 \cdot 9$ \\
\hline \multicolumn{9}{|l|}{ Physical activity } \\
\hline Deficient & 17055 & $74 \cdot 1$ & 11229 & $74 \cdot 3$ & 5826 & 73.7 & 1936 & $75 \cdot 6$ \\
\hline Compliant & 6002 & $25 \cdot 8$ & 3950 & $25 \cdot 7$ & 2052 & $26 \cdot 3$ & 587 & 24.4 \\
\hline \multicolumn{9}{|l|}{ Wealth index quintile } \\
\hline 1 - poorest & 14651 & $37 \cdot 4$ & 10586 & 37.3 & 4065 & $37 \cdot 6$ & 1303 & 38.5 \\
\hline 2 & 7106 & 23.5 & 4989 & $23 \cdot 6$ & 2117 & $23 \cdot 0$ & 642 & $23 \cdot 4$ \\
\hline 3 & 4834 & $22 \cdot 7$ & 3416 & 22.5 & 1418 & $23 \cdot 4$ & 401 & $18 \cdot 7$ \\
\hline 4 - wealthiest & 2668 & $16 \cdot 4$ & 1853 & $16 \cdot 6$ & 815 & $16 \cdot 0$ & 285 & $19 \cdot 4$ \\
\hline \multicolumn{9}{|l|}{ Household food security } \\
\hline Food secure & 9994 & $36 \cdot 7$ & 6744 & 34.9 & 3250 & $41 \cdot 1$ & 1051 & $40 \cdot 9$ \\
\hline Mild food insecurity & 10435 & $35 \cdot 8$ & 7455 & $36 \cdot 2$ & 2980 & 34.9 & 981 & $37 \cdot 0$ \\
\hline Moderate food insecurity & 5317 & $16 \cdot 8$ & 3891 & 17.5 & 1426 & $15 \cdot 0$ & 374 & $13 \cdot 2$ \\
\hline Severe food insecurity & 3509 & $10 \cdot 7$ & 2751 & 11.4 & 759 & $9 \cdot 0$ & 225 & 8.9 \\
\hline \multicolumn{9}{|l|}{ Area } \\
\hline Urban & 29917 & $77 \cdot 3$ & 15494 & $76 \cdot 7$ & 6423 & $78 \cdot 7$ & 2037 & $77 \cdot 4$ \\
\hline Rural $^{\S}$ & 7342 & $22 \cdot 7$ & 5350 & $23 \cdot 3$ & 1992 & $21 \cdot 3$ & 594 & $22 \cdot 6$ \\
\hline
\end{tabular}

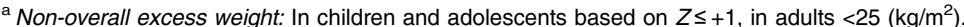

${ }^{\mathrm{b}}$ Overall excess weight: In children and adolescents based on $Z>+1$, in adults $\geq 25\left(\mathrm{~kg} / \mathrm{m}^{2}\right)$.

${ }^{c}$ Conservative overweight: In children and adolescents based on $Z>+2$, in adults $\geq 30\left(\mathrm{~kg} / \mathrm{m}^{2}\right)$.

${ }^{*}[N]$.

${ }^{+} n$ may be less than $[N]$ due to missing values.

₹ Since percentages have incorporated the complex design of the sample, they may not coincide with those calculated based on absolute values.

$\S$ The rural category included suburban population centres close to small cities, towns in rural areas distant from small towns and places dispersed or very distant from rural towns.

which the prevalence decreased in relative terms, while excess weight $v$. adequate weight remained stable (Fig. 1).

\section{EER and absolute energy intake}

For men, EER was $2146 \mathrm{kcal} / \mathrm{d}$ (95\% CI 1985, 2308) and average intake was $2117 \mathrm{kcal} / \mathrm{d}$ (95\% CI 1969, 2264). For women, EER was $1796 \mathrm{kcal} / \mathrm{d}(95 \%$ CI 1760,1832$)$ and intake was $1818 \mathrm{kcal} / \mathrm{d}$ (95\% CI 1740, 1896). EER and average intake by age group were as follows: EER of $1100 \mathrm{kcal} / \mathrm{d}$ $(95 \%$ CI 1075, 1126) and average intake of $1614 \mathrm{kcal} / \mathrm{d}(95 \%$ CI 1320, 1908) for the 1-4-year-old age group; EER of 1533 $\mathrm{kcal} / \mathrm{d}(95 \%$ CI 1421, 1645) and average intake of $1787 \mathrm{kcal} /$ d $(95 \%$ CI 1573, 2003) for the 5-12-year-old age group; EER of $2285 \mathrm{kcal} / \mathrm{d}(95 \%$ CI 2214, 2357) and intake of 2367 $\mathrm{kcal} / \mathrm{d}$ (95\% CI 2235, 2500) for the 13-17-year-old age group; EER of $2339 \mathrm{kcal} / \mathrm{d}(95 \%$ CI 2295, 2382) and intake of $2305 \mathrm{kcal} / \mathrm{d}(95 \%$ CI 2195,2416$)$ for the $18-26$-year-old age group; EER of $2194 \mathrm{kcal} / \mathrm{d}(95 \%$ CI 2149, 2239) and intake of $2001 \mathrm{kcal} / \mathrm{d}(95 \%$ CI 1925, 2077) for the $27-$ 49-year-old age group and EER of $2087 \mathrm{kcal} / \mathrm{d}$ (95\% CI 2050, 2125) and average intake of $1797 \mathrm{kcal} / \mathrm{d}$ (95\% CI $1731,1862)$ for the 50-64-year-old age group. Supplementary Tables S1 and S2 of Supplementary material present absolute energy intake and adjusted differences for the categories of the covariables studied, according to excess weight categories.

\section{Relative energy consumption (ratio of $(\mathrm{kcal} / \mathrm{d}) / E E R \pm S E-$ Rkeer)}

With regard to the categories of the covariables studied, children from 1 to 4 years old with CEW had the highest Rkeer $(1.55 \pm 0 \cdot 16)$ and adults between 50 and 64 years old without CEW had the lowest $(0 \cdot 86 \pm 0 \cdot 83)$. Ethnicity was the only variable that presented statistically significant differences among subjects with excess weight. Supplementary Tables S3 and S4 of Supplementary material show these ratios according to the categories of the covariables studied.

\section{Protein intake in grams per $1000 \mathrm{kcal}$ (g/1000)}

Average protein intake was $33 \cdot 1 \mathrm{~g} / 1000$ (95\% CI 31.9, 34.2) for men and $33.4 \mathrm{~g} / 1000(95 \% \mathrm{CI} 32.7,34 \cdot 1)$ for women $(P$ $=0.668)$. Average protein intake was $32.7 \mathrm{~g} / 1000(95 \% \mathrm{CI}$ $31.8,36.6)$ for the 1-4-year-old group, $31.8 \mathrm{~g} / 1000(95 \%$ CI $30 \cdot 8,32 \cdot 8$ ) for the 5-12-year-old group, $32 \cdot 0 \mathrm{~g} / 1000$ (95 $\%$ CI $30 \cdot 2,33 \cdot 8$ ) for the $13-17$-year-old group, $32 \cdot 8 \mathrm{~g} / 1000$ (95\% CI 32.0, 34.0) for the 18-26-year-old group, $34.5 \mathrm{~g} /$ $1000(95 \%$ CI $32 \cdot 8,36 \cdot 2)$ for the $27-49$-year-old group and 


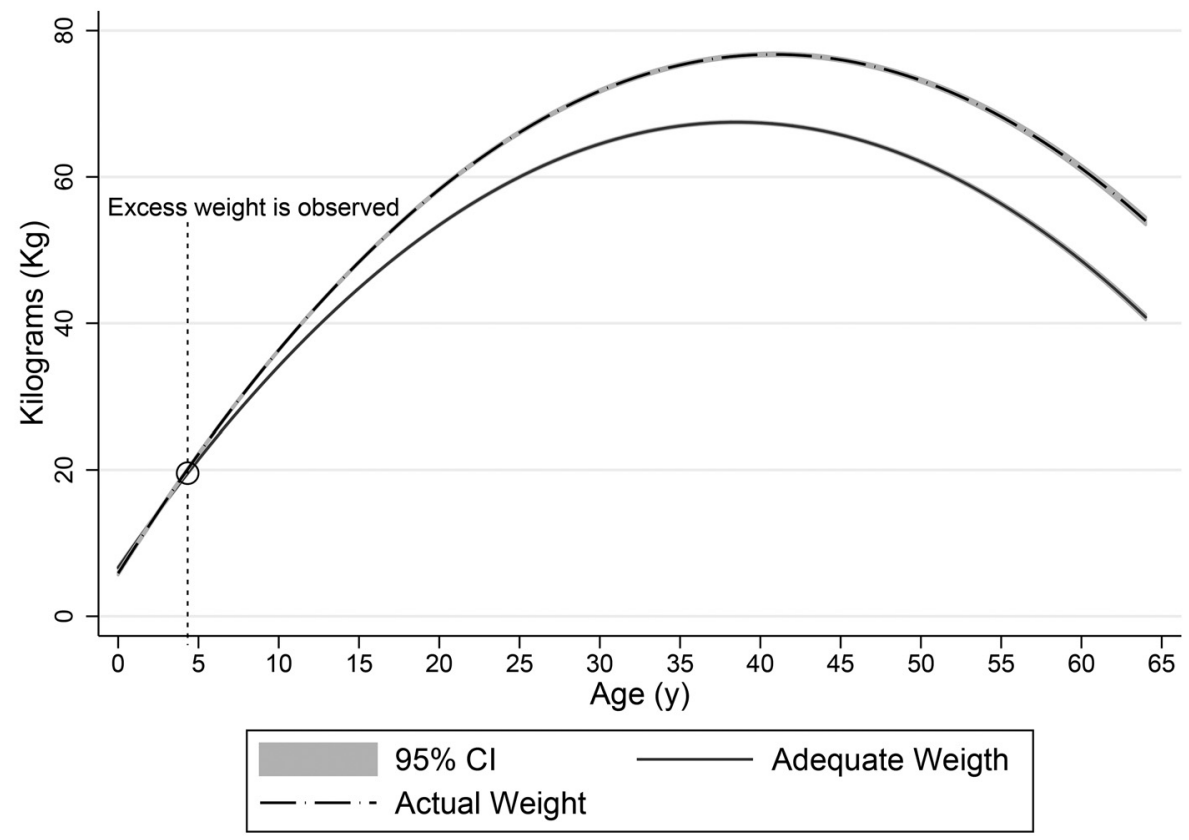

Fig. 1. Adequate weight and current weight according to age (Colombia, 2015).

$34.0 \mathrm{~g} / 1000(95 \%$ CI 32.6, 35.5) for the 50-64-year-old group $(P=0 \cdot 002)$. No differences were found among the categories of the covariables studied when comparing protein intake $(\mathrm{g} / 1000)$ for subjects with and without OEW. For 18-26-year olds and black subjects, statistically significant differences in protein intake $(\mathrm{g} / 1000)$ were found when comparing subjects with and without CEW. Supplementary Tables S5 and S6 of Supplementary material present these differences.

\section{Protein intake in grams per kilogram of adequate weight ( $\mathrm{g} / \mathrm{kg}$ per $d$-Rprotein)}

Average intake was $1.69 \mathrm{~g} / \mathrm{kg}$ per d (95\% CI 1.58, 1.79) for men and $1.59 \mathrm{~g} / \mathrm{kg}$ per d $(95 \%$ CI $1.40,1.78)$ for women $(P$ $=0.383), 3 \cdot 85 \mathrm{~g} / \mathrm{kg}$ per d (95\% CI 3.46, 4.24) for children between 1 and 4 years of age, $2 \cdot 25 \mathrm{~g} / \mathrm{kg}$ per $\mathrm{d}(95 \% \mathrm{CI}$ $2 \cdot 11,2 \cdot 40$ ) for children between 5 and 12 years of age, 1.53 $\mathrm{g} / \mathrm{kg}$ per d (95\% CI 1.33, 1.74) for adolescents between 13 and 17 years of age, $1.26 \mathrm{~g} / \mathrm{kg}$ per d (95\% CI 1.21, 1.31) for adults between 18 and 26 years of age, $1.12 \mathrm{~g} / \mathrm{kg}$ per $\mathrm{d}$ (95\% CI 1.08, 1.17) for adults between 27 and 49 years of age and $1.04 \mathrm{~g} / \mathrm{kg}$ per d $(95 \%$ CI $0.98,1.10)$ for adults between 50 and 64 years of age $(P<0 \cdot 0001)$. Children with OEW had the highest Rprotein intake (average 3.94, $\pm 0 \cdot 25$ SD). Fig. 2 summarises the findings on energy and protein intake, by age group. Tables 2 and 3 summarize the findings of protein intake $(\mathrm{g} / \mathrm{kg}$ per $\mathrm{d})$ regarding nutritional status.

\section{Relative contribution of protein to total energy, AMDR (\%)}

Proteins made up $13.27 \%(95 \%$ CI 12.88, 13.66) of the total energy consumed by men and $13 \cdot 31 \%(95 \%$ CI 13.06, 13.56) of the total consumed by women $(P=0 \cdot 834)$. The contribution of protein to total energy intake was $13.07 \%(95 \% \mathrm{CI}$ $12 \cdot 72,13.43)$ for the $1-4$-year-old age group, $12 \cdot 71 \%(95 \%$
CI $12 \cdot 30,13 \cdot 11)$ for the 5 -12-year-old age group, $12 \cdot 82 \%$ (95\% CI 12.09, 13.54) for the 13-17-year-old age group, $13.13 \%(95 \%$ CI $12.78,13.47)$ for the $18-26$-year-old age group, $13.79 \%(95 \%$ CI 13.11, 14.46) for the 27-49-year-old age group and $13.61 \%$ (95\% CI 13.05, 14.18) for the 50-64year-old age group. Supplementary Fig. S1 of Supplementary material presents the AMDR of protein (\%) to total energy intake.

\section{Discussion}

This work found that excess weight in the Colombian population is detectable by the age of 4 years, which may suggest that the excessive energy and protein consumption described herein may be the causal pathway to excess weight and obesity at an early age. Once excess weight begins, it increases steadily until age 40, and although it decreases after age 40, there continues to be a gap between adequate and current weight (Fig. 1). With regard to current mean energy and protein intake, no significant differences were found between subjects with and without OEW and CEW, with the exception of ethnicity. In general, the Rkeer was found to fall within the suggested range of 90-110\%, except for children between 1 and 4 years old (144 and $155 \%$ ). Given the low level of physical activity on the part of the Colombian population ${ }^{(7)}$, if a range of $0 \cdot 8-1.2 \mathrm{~g} / \mathrm{kg}$ per $\mathrm{d}$ is considered adequate protein consumption regardless of the nutritional condition of the subjects $^{(30)}$, then the population consumes more protein than the limit. Nevertheless, long-term protein consumption of up to $2 \cdot 0 \mathrm{~g} / \mathrm{kg}$ per $\mathrm{d}$ has been considered to be safe ${ }^{(30)}$, and protein intake has been considered inadequate when the relative protein contribution is under the $\mathrm{RIEN}^{(14)}$ recommendation of $15 \%$.

The prevalence of overweight and obesity among Colombian adults was greater for women than for men: 8 


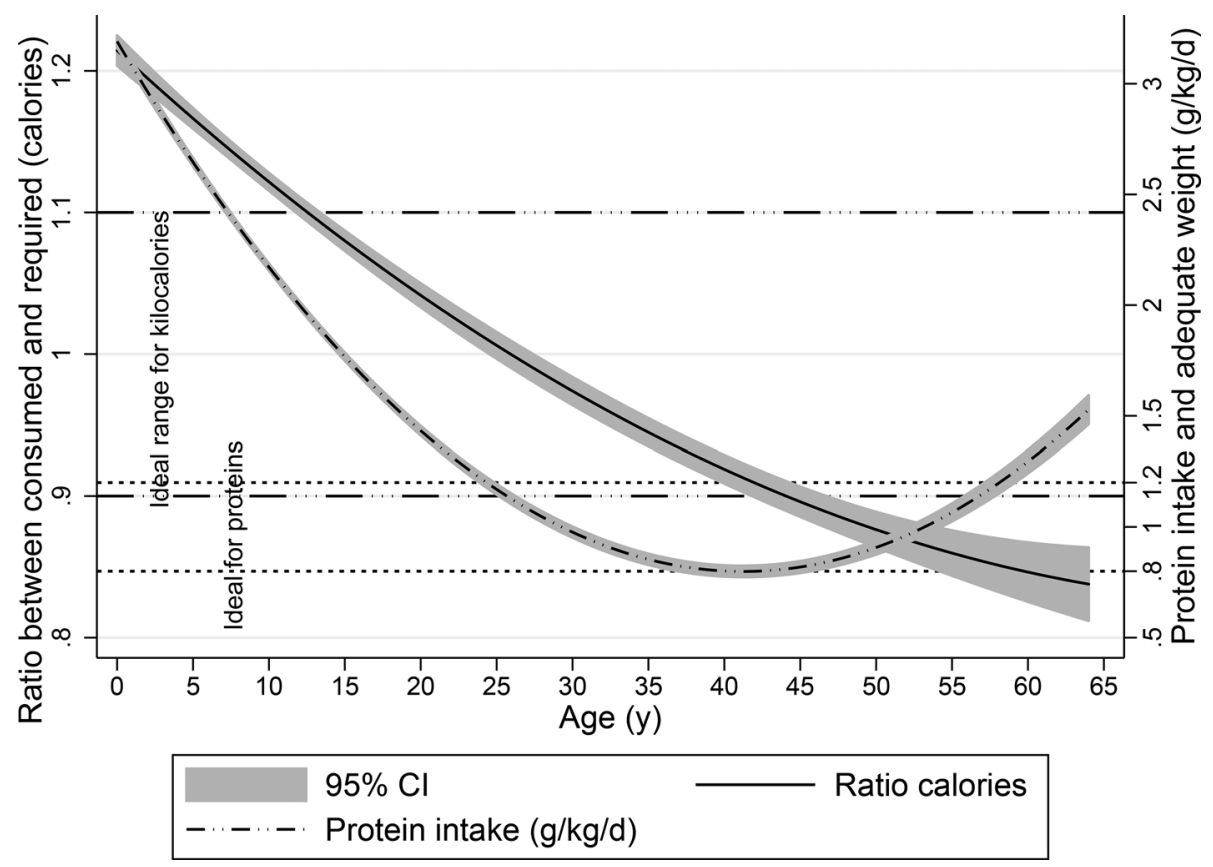

Fig. 2. Trends in calorie and protein intake by age; the ratio between energy consumed and required; grams of protein per kilogram of adequate weight (g/kg per d) (Colombia, 2015).

and $6.8 \%$, respectively ${ }^{(7)}$. Since overweight, obesity, OEW and CEW cannot be attributed to the prior day's energy or macronutrient intake, as expected, absolute and relative energy and protein intake did not differ according to the nutritional condition of these subjects. Excess weight is a long-term condition that is related only to usual intake and not to current intake based on a single $24 \mathrm{HR}^{(31)}$.

Proteins are one of the most commonly studied macronutrients. They are required for growth and development, and for the synthesis of essential amino acids ${ }^{(30)}$. The U.S. National Academy of Medicine (formerly the Institute of Medicine $[\mathrm{IOM}])$ established the estimated average requirement (EAR) and recommended dietary requirement (RDA) in grams per kilograms per day $(\mathrm{g} / \mathrm{kg}$ per d) (EAR of $0.66 \mathrm{~g} / \mathrm{kg}$ per d and RDA of $0.80 \mathrm{~g} / \mathrm{kg}$ per d) ${ }^{(32)}$, while RIEN established the relative contribution of protein to total energy intake, with a relative contribution between 10 and $20 \%$ (equivalent to $45 \mathrm{~g} / \mathrm{d}$ for children between 2 and 5 years of age and up to $103 \mathrm{~g} / \mathrm{d}$ for subjects between 14 and 17 years old $)^{(14)}$. In all cases studied herein, the estimates exceeded both IOM and RIEN recommendations and were similar to those reported by the 2003-2004 National Health and Nutrition Examination Survey (NHANES): average of $56 \mathrm{~g} / \mathrm{d} \pm 14 \mathrm{sD}$ for children and adolescents, $91 \pm 22 \mathrm{~g} / \mathrm{d}$ for subjects between 19 and 30 years of age, $86 \mathrm{~g} / \mathrm{d} \pm 20 \mathrm{sD}$ for adults for adults between 30 and 50 years and $66 \pm 17 \mathrm{~g} / \mathrm{d}$ for adults over 50 years old ${ }^{(33)}$. NHANES reported that between 1999 and 2016, the AMDR for total proteins (both animal and vegetable) increased from 15.5 to $16.4 \%$ in the U.S. population over 20 years of age ${ }^{(12)}$. Furthermore, protein intake in 2003-6 did not differ significantly from protein intake in $2015-16^{(34)}$.

Excess protein intake has been associated with increased mortality from cardiovascular disease, with a hazard ratio of
1.08 per $10 \%$ increase in energy consumption $(95 \% \mathrm{CI}$ $1.01,1 \cdot 16 ; P=0.04$ for the trend). This was found among those who had at least one risk factor associated with smoking, heavy alcohol consumption, overweight, obesity or sedentarism ${ }^{(35,36)}$. In a cohort study of Swedish women between 30 and 49 years old with a 16-year follow-up, regular consumption of high-protein, low-carbohydrate diets was associated with a greater risk of cardiovascular disease, with an incidence rate of $1.05\left(95 \%\right.$ CI 1.02, 1.08) ${ }^{(37)}$. A case-control study of the Korean population between 30 and 76 years old reported an inverse association, though not statistically significant, between vegetable protein intake and the prevalence of colorectal adenoma, after adjusting for age, total energy intake, waist circumference, BMI, HDL-cholesterol, fasting glucose, alcohol intake and smoking. Nevertheless, when adjusted by potential confounders, that association was not significant (OR 0.54 [95\% CI $0.27,1.11] ; P=0.13$ for the trend) ${ }^{(38)}$. With regard to the risk of type 2 diabetes mellitus, a cohort study of the population in China between 20 and 74 years old found that, over the long term, diets low in carbohydrates, high in fats and high in proteins were associated with a higher risk of type 2 diabetes for subjects who consumed excess calories (RR 1.64 [95\% CI 1.03, 2.61]; $P=0.040$ for the trend $)^{(39)}$. A cohort study with an Iranian population over 20 years old found that the risk of incidence of chronic kidney disease increased with an increase in high-protein, lowcarbohydrate diets (OR 1.48 [95\% CI 1.03, 2.15]; $P=0.027$ for the trend $)^{(40)}$. Excess protein consumption of over $0 \cdot 8$ $\mathrm{g} / \mathrm{kg}$ per $\mathrm{d}$ increased intraglomerular pressure and complications from chronic kidney disease ${ }^{(41)}$. Lastly, the EATLancet Commission has presented robust evidence of the health and environmental consequences from consuming over $0.8 \mathrm{~g} / \mathrm{kg}$ per $\mathrm{d}$ of protein, or $\geq 10 \%$ of the AMDR, predominantly from animal sources. The commission reported 
Table 2. Adjusted difference in the ratio between protein intake and adequate weight ( $\mathrm{g} / \mathrm{kg}$ per $\mathrm{d}$ ), between overall excess weight ${ }^{\mathrm{a}}$ and non-overall excess weight ${ }^{\mathrm{b}}$ for subjects in the Colombian population, 2015

\begin{tabular}{|c|c|c|c|c|c|c|c|c|c|c|}
\hline \multirow[b]{2}{*}{ Variable } & \multicolumn{4}{|c|}{ Overall excess weight } & \multicolumn{4}{|c|}{ Non-overall excess weight } & \multirow[b]{2}{*}{ Adjusted difference $^{\dagger}$} & \multirow[b]{2}{*}{$P$ Interaction } \\
\hline & $n^{*}$ & Mean & SE & $P$ value & $n^{\star}$ & Mean & SE & $P$ value & & \\
\hline Sex & & & & 0.437 & & & & 0.362 & & \\
\hline Male & 4062 & 1.72 & 0.06 & & 10240 & 1.67 & 0.05 & & $0.03(-0.06,0.11)$ & 0.554 \\
\hline Female & 4353 & $1 \cdot 61$ & 0.13 & & 10604 & 1.58 & 0.08 & & $0.03(-0.10,0.16)$ & 0.692 \\
\hline Age (years) & & & & $<0.0001$ & & & & $<0.0001$ & & \\
\hline $1-4$ & 1780 & 3.94 & 0.25 & & 4514 & $3 \cdot 81$ & $0 \cdot 17$ & & $0.12(-0.09,0.33)$ & 0.269 \\
\hline $5-12$ & 1751 & $2 \cdot 24$ & 0.07 & & 4424 & $2 \cdot 25$ & 0.07 & & $-0.01(-0.10,0.07)$ & 0.745 \\
\hline $13-17$ & 1942 & 1.54 & 0.12 & & 5026 & 1.53 & $0 \cdot 10$ & & $-0.02(-0.11,0.06)$ & 0.615 \\
\hline $18-26$ & 574 & 1.25 & 0.04 & & 1413 & 1.27 & 0.03 & & $-0.04(-0.14,0.05)$ & 0.343 \\
\hline $27-49$ & 1483 & $1 \cdot 12$ & 0.02 & & 1462 & 1.13 & 0.03 & & $0.00(-0.07,0.07)$ & 0.957 \\
\hline $50-64$ & 750 & $1 \cdot 10$ & 0.04 & & 1677 & 1.03 & 0.03 & & $0.03(-0.06,0.12)$ & 0.469 \\
\hline Abdominal obesity ${ }^{\ddagger}$ & & & & 0.265 & & & & 0.311 & & \\
\hline Yes & 4358 & 1.64 & 0.08 & & 550 & 1.69 & $0 \cdot 10$ & & $-0.03(-0.18,0.12)$ & 0.710 \\
\hline No & 957 & 1.72 & 0.12 & & 3372 & $1 \cdot 61$ & 0.06 & & $0.08(-0.07,0.22)$ & 0.590 \\
\hline Physical activity & & & & 0.758 & & & & 0.641 & & \\
\hline Deficient & 5826 & 1.67 & 0.09 & & 11229 & 1.64 & 0.05 & & $0.03(-0.04,0.11)$ & 0.360 \\
\hline Compliant & 2052 & 1.64 & 0.06 & & 3950 & 1.65 & 0.05 & & $0.01(-0.09,0.10)$ & 0.850 \\
\hline Household size & & & & 0.945 & & & & 0.715 & & \\
\hline Single person & 286 & 1.63 & $0 \cdot 10$ & & 237 & 1.75 & $0 \cdot 12$ & & $-0.08(-0.38,0.21)$ & 0.579 \\
\hline $2-4$ & 4919 & 1.65 & 0.06 & & 10227 & $1 \cdot 62$ & 0.04 & & $0.01(-0.06,0.08)$ & 0.785 \\
\hline $5-6$ & 2169 & 1.72 & 0.09 & & 6860 & $1 \cdot 67$ & 0.06 & & $0.06(-0.04,0.16)$ & 0.214 \\
\hline $7+$ & 1041 & 1.59 & 0.14 & & 3520 & 1.57 & 0.09 & & $0.05(-0.12,0.23)$ & 0.550 \\
\hline Household food security & & & & 0.026 & & & & 0.082 & & \\
\hline Food secure & 3250 & 1.71 & 0.09 & & 6744 & 1.68 & 0.05 & & $0.01(-0.09,0.11)$ & 0.874 \\
\hline Mild food insecurity & 2980 & 1.65 & 0.06 & & 7455 & 1.62 & 0.06 & & $0.04(-0.04,0.12)$ & 0.287 \\
\hline Moderate food insecurity & 1426 & 1.60 & 0.11 & & 3891 & 1.54 & 0.06 & & $0.07(-0.07,0.21)$ & 0.344 \\
\hline Severe food insecurity & 759 & 1.58 & 0.08 & & 2750 & $1 \cdot 63$ & 0.07 & & $-0.06(-0.19,0.08)$ & 0.425 \\
\hline Wealth index quintile & & & & 0.534 & & & & 0.579 & & \\
\hline 1 - poorest & 4065 & 1.74 & $0 \cdot 17$ & & 10586 & 1.66 & $0 \cdot 11$ & & $0.07(-0.06,0.20)$ & 0.266 \\
\hline 2 & 2117 & $1 \cdot 61$ & 0.07 & & 4989 & 1.65 & 0.06 & & $-0.06(-0.15,0.03)$ & $0 \cdot 217$ \\
\hline 3 & 1418 & 1.58 & 0.07 & & 3416 & 1.57 & 0.07 & & $-0.01(-0.13,0.10)$ & 0.805 \\
\hline 4 - wealthiest & 815 & $1 \cdot 66$ & 0.08 & & 1853 & $1 \cdot 61$ & 0.07 & & $0.08(-0.08,0.25)$ & 0.318 \\
\hline Ethnicity & & & & 0.003 & & & & 0.032 & & \\
\hline Black/Afro & 692 & 1.40 & 0.07 & & 1871 & 1.47 & 0.08 & & $-0.11(-0.26,0.04)$ & 0.161 \\
\hline Indigenous & 683 & $1 \cdot 29$ & 0.07 & & 2083 & 1.46 & 0.08 & & $-0.25(-0.43,-0.08)$ & 0.006 \\
\hline Mestizo & 7011 & 1.63 & 0.08 & & 16827 & 1.65 & 0.06 & & $0.05(-0.02,0.12)$ & $0 \cdot 140$ \\
\hline Education of head of household & & & & $0 \cdot 107$ & & & & $0 \cdot 131$ & & \\
\hline Preschool or less & 2119 & 1.54 & 0.06 & & 6052 & 1.58 & 0.06 & & $-0.02(-0.10,0.06)$ & 0.665 \\
\hline Primary & 2950 & 1.69 & 0.06 & & 7062 & $1 \cdot 64$ & 0.05 & & $0.02(-0.06,0.09)$ & 0.659 \\
\hline Secondary & 2750 & $1 \cdot 70$ & 0.11 & & 6584 & 1.65 & 0.07 & & $0.06(-0.05,0.17)$ & 0.277 \\
\hline Post-secondary & 563 & 1.72 & 0.10 & & 995 & $1 \cdot 70$ & 0.07 & & $-0.00(-0.23,0.22)$ & 0.971 \\
\hline Area & & & & 0.015 & & & & 0.010 & & \\
\hline Urban & 6423 & 1.71 & 0.09 & & 15494 & 1.68 & 0.06 & & $0.04(-0.05,0.12)$ & 0.383 \\
\hline Rural ${ }^{\S}$ & 1992 & 1.47 & 0.04 & & 5350 & 1.47 & 0.05 & & $0.00(-0.09,0.09)$ & 0.999 \\
\hline Region & & & & 0.948 & & & & 0.964 & & \\
\hline Central & 2063 & 1.60 & $0 \cdot 10$ & & 4956 & $1 \cdot 62$ & 0.08 & & $-0.02(-0.10,0.06)$ & 0.603 \\
\hline Atlantic & 1481 & $1 \cdot 84$ & 0.29 & & 4017 & $1 \cdot 67$ & 0.17 & & $0.16(-0.11,0.44)$ & 0.240 \\
\hline Oriental & 1492 & 1.59 & 0.04 & & 3672 & $1 \cdot 63$ & 0.04 & & $-0.01(-0.11,0.08)$ & $0 \cdot 767$ \\
\hline Pacific & 1058 & 1.44 & $0 \cdot 10$ & & 2813 & 1.48 & 0.09 & & $-0.06(-0.17,0.05)$ & 0.270 \\
\hline Bogotá & 568 & 1.72 & 0.10 & & 1485 & 1.68 & 0.09 & & $0.06(-0.11,0.23)$ & 0.484 \\
\hline National territories & 1753 & 1.81 & 0.10 & & 3901 & 1.76 & 0.15 & & $0.04(-0.15,0.24)$ & 0.675 \\
\hline
\end{tabular}

a Overall excess weight: In children and adolescents based on $Z>+1$, in adults $\geq 25\left(\mathrm{~kg} / \mathrm{m}^{2}\right)$.

${ }^{\mathrm{b}}$ Non-overall excess weight: In children and adolescents based on $Z \leq+1$, in adults $<25\left(\mathrm{~kg} / \mathrm{m}^{2}\right)$.

* Overall excess weight $n$ may be less than 8415 for missing values. Non-overall excess weight $n$ may be less than 20844 for missing values.

${ }^{\dagger}$ Adjusted difference and $95 \%$ confidence intervals calculated with a linear regression model based on intake/day of kilocalories as the dependent variable and predictors that included indicator variables for each socio-demographic correlate, Non-overall excess weight (Overall excess weight) and cross-product (interaction) terms between overweight and indicator variables of the correlate. In addition, the linear regression model was adjusted by the following covariables: sex, age, physical activity, household size, food security, wealth index, ethnicity, education of the head of household, area and region. The complex sampling survey design was used in all multivariate regression models.

${ }^{\ddagger}$ In men $\geq 90 \mathrm{~cm}$, in women $\geq 80 \mathrm{~cm}$.

$\S$ The rural category included suburban population centres close to small cities, towns in rural areas distant from small towns and places dispersed or very distant from rural towns.

health consequences such as an association with overall mortality from cancer, cardiovascular disease and type 2 diabetes, and an environmental impact on the production of greenhouse gases (methane, nitrous oxide and carbon dioxide) from food production $^{(42)}$.

\section{Public policy implications}

The development of the science of nutrition cannot be understood without the institutions and policies that are associated with them ${ }^{(43)}$. In this case, energy and protein intake is not 
Table 3. Adjusted difference in the ratio between protein intake and adequate weight ( $\mathrm{g} / \mathrm{kg} \mathrm{per} \mathrm{d),} \mathrm{between} \mathrm{conservative} \mathrm{overweight}{ }^{\mathrm{a}}$ and non-conservative overweight $^{\mathrm{b}}$ for subjects in the Colombian population, 2015

\begin{tabular}{|c|c|c|c|c|c|c|c|c|c|c|}
\hline \multirow[b]{2}{*}{ Variable } & \multicolumn{4}{|c|}{ Conservative overweight } & \multicolumn{4}{|c|}{ Non-conservative overweight } & \multirow[b]{2}{*}{ Adjusted difference $^{\dagger}$} & \multirow[b]{2}{*}{$P$ interaction } \\
\hline & $n^{*}$ & Mean & SD & $P$ value & $n^{*}$ & Mean & SD & $P$ value & & \\
\hline Sex & & & & 0.756 & & & & 0.340 & & \\
\hline Male & 1264 & 1.70 & 0.07 & & 13038 & 1.68 & 0.05 & & $-0.01(-0.11,0.09)$ & 0.814 \\
\hline Female & 1367 & 1.64 & $0 \cdot 16$ & & 13590 & 1.59 & 0.09 & & $0.06(-0.10,0.22)$ & 0.483 \\
\hline Age (years) & & & & $<0.0001$ & & & & $<0.0001$ & & \\
\hline $1-4$ & 568 & 3.91 & 0.30 & & 5726 & $3 \cdot 84$ & $0 \cdot 18$ & & $0.04(-0.22,0.31)$ & 0.738 \\
\hline $5-12$ & 550 & $2 \cdot 27$ & 0.09 & & 5625 & $2 \cdot 25$ & 0.07 & & $0.00(-0.10,0.11)$ & 0.979 \\
\hline $13-17$ & 602 & 1.45 & $0 \cdot 11$ & & 6366 & 1.54 & $0 \cdot 10$ & & $-0.09(-0.20,0.01)$ & 0.085 \\
\hline $18-26$ & 185 & $1 \cdot 17$ & 0.06 & & 1802 & $1 \cdot 27$ & 0.03 & & $-0.13(-0.27,0.02)$ & 0.079 \\
\hline $27-49$ & 438 & $1 \cdot 10$ & 0.04 & & 4507 & $1 \cdot 13$ & 0.02 & & $-0.02(-0.11,0.07)$ & 0.666 \\
\hline $50-64$ & 247 & $1 \cdot 15$ & 0.07 & & 2180 & 1.03 & 0.03 & & $0.13(-0.02,0.29)$ & 0.097 \\
\hline Abdominal obesity ${ }^{\ddagger}$ & & & & 0.599 & & & & 0.618 & & \\
\hline Yes & 1808 & 1.64 & 0.09 & & 3100 & 1.65 & 0.07 & & $0.00(-0.10,0.11)$ & 0.935 \\
\hline No & 31 & $1 \cdot 78$ & 0.30 & & 4298 & 1.63 & 0.07 & & $0.06(-0.42,0.54)$ & 0.791 \\
\hline Physical activity & & & & 0.940 & & & & 0.878 & & \\
\hline Deficient & 1936 & 1.67 & $0 \cdot 10$ & & 15119 & 1.65 & 0.06 & & $0.02(-0.07,0.11)$ & 0.618 \\
\hline Compliant & 587 & 1.68 & $0 \cdot 10$ & & 5415 & 1.65 & 0.05 & & $0.03(-0.11,0.17)$ & 0.695 \\
\hline Household size & & & & 0.187 & & & & 0.516 & & \\
\hline Single person & 112 & 1.54 & 0.14 & & 411 & 1.73 & 0.09 & & $-0.19(-0.52,0.13)$ & 0.244 \\
\hline $2-4$ & 1603 & $1 \cdot 62$ & 0.08 & & 13543 & 1.63 & 0.05 & & $-0.02(-0.11,0.07)$ & 0.627 \\
\hline $5-6$ & 642 & 1.75 & 0.11 & & 8387 & $1 \cdot 68$ & 0.06 & & $0.07(-0.07,0.20)$ & 0.337 \\
\hline $7+$ & 274 & 1.79 & 0.22 & & 4287 & 1.56 & 0.09 & & $0.26(-0.05,0.58)$ & 0.101 \\
\hline Household food security & & & & 0.613 & & & & 0.026 & & \\
\hline Food secure & 1051 & 1.71 & 0.12 & & 8943 & 1.69 & 0.05 & & $-0.02(-0.15,0.12)$ & 0.791 \\
\hline Mild food insecurity & 981 & 1.63 & 0.07 & & 9454 & 1.63 & 0.06 & & $0.02(-0.09,0.12)$ & 0.782 \\
\hline Moderate food insecurity & 374 & 1.61 & 0.17 & & 4943 & 1.55 & 0.07 & & $0.09(-0.15,0.33)$ & 0.453 \\
\hline Severe food insecurity & 225 & 1.71 & $0 \cdot 12$ & & 3284 & 1.61 & 0.07 & & $0.12(-0.11,0.35)$ & 0.312 \\
\hline Wealth index quintile & & & & 0.599 & & & & 0.551 & & \\
\hline 1 - poorest & 1303 & 1.77 & 0.21 & & 13348 & 1.68 & 0.12 & & $0.06(-0.08,0.20)$ & 0.374 \\
\hline 2 & 642 & 1.54 & 0.07 & & 6464 & 1.65 & 0.06 & & $-0.12(-0.25,0.00)$ & 0.057 \\
\hline 3 & 401 & $1 \cdot 64$ & 0.08 & & 4433 & 1.57 & 0.07 & & $0.04(-0.11,0.20)$ & 0.574 \\
\hline 4 - wealthiest & 285 & $1 \cdot 64$ & $0 \cdot 10$ & & 2383 & $1 \cdot 62$ & 0.07 & & $0.06(-0.14,0.26)$ & 0.551 \\
\hline Ethnicity & & & & 0.027 & & & & 0.012 & & \\
\hline Black/Afro & 268 & 1.41 & 0.09 & & 2295 & 1.45 & 0.07 & & $-0.07(-0.27,013)$ & 0.496 \\
\hline Indigenous & 201 & 1.50 & $0 \cdot 13$ & & 2565 & 1.42 & 0.07 & & $-0.07(-0.39,0.24)$ & 0.643 \\
\hline Mestizo & 2152 & $1 \cdot 70$ & $0 \cdot 10$ & & 21686 & 1.66 & 0.06 & & $0.04(-0.06,0.13)$ & 0.449 \\
\hline Education of the head & & & & 0.046 & & & & $0 \cdot 116$ & & \\
\hline Preschool or less & 673 & 1.50 & 0.08 & & 7498 & 1.57 & 0.05 & & $-0.05(-0.19,0.09)$ & 0.467 \\
\hline Primary & 894 & 1.69 & 0.07 & & 9118 & 1.65 & 0.05 & & $0.02(-0.08,0.13)$ & 0.657 \\
\hline Secondary & 874 & $1 \cdot 72$ & $0 \cdot 15$ & & 8460 & $1 \cdot 66$ & 0.07 & & $0.05(-0.09,0.19)$ & 0.493 \\
\hline Post-secondary & 179 & 1.85 & $0 \cdot 13$ & & 1379 & 1.69 & 0.06 & & $0.14(-0.12,0.41)$ & 0.278 \\
\hline Area & & & & 0.127 & & & & 0.007 & & \\
\hline Urban & 2037 & 1.70 & $0 \cdot 11$ & & 19880 & 1.66 & 0.06 & & $0.01(-0.09,0.11)$ & 0.865 \\
\hline Rural $^{\S}$ & 594 & 1.52 & 0.06 & & 6748 & 1.47 & 0.04 & & $0.09(-0.04,0.21)$ & 0.172 \\
\hline Region & & & & 0.812 & & & & 0.973 & & \\
\hline Central & 685 & 1.59 & 0.12 & & 6334 & 1.62 & 0.09 & & $-0.04(-0.16,0.08)$ & 0.491 \\
\hline Atlantic & 536 & $1 \cdot 88$ & 0.30 & & 4962 & $1 \cdot 70$ & 0.19 & & $0.15(-0.07,0.36)$ & 0.171 \\
\hline Oriental & 404 & 1.53 & 0.08 & & 4760 & 1.63 & 0.04 & & $-0.08(-0.26,0.09)$ & 0.344 \\
\hline Pacific & 339 & 1.45 & $0 \cdot 10$ & & 3532 & 1.47 & 0.09 & & $-0.02(-0.18,0.13)$ & 0.749 \\
\hline Bogotá & 136 & 1.86 & 0.15 & & 1917 & 1.69 & 0.09 & & $0.15(-0.12,0.43)$ & 0.272 \\
\hline National territories & 531 & 1.83 & 0.12 & & 5123 & 1.77 & 0.14 & & $0.05(-0.21,0.30)$ & 0.722 \\
\hline
\end{tabular}

${ }^{a}$ Conservative overweight: In children and adolescents based on $Z>+2$, in adults $\geq 30\left(\mathrm{~kg} / \mathrm{m}^{2}\right)$.

${ }^{\mathrm{b}}$ Non-conservative overweight: In children and adolescents based on $Z \leq+2$, in adults $<30\left(\mathrm{~kg} / \mathrm{m}^{2}\right)$.

* Conservative overweight $n$ may be less than 2631 for missing values. Non-conservative overweight $n$ may be less than 26628 for missing values.

${ }^{\dagger}$ Adjusted difference and $95 \%$ confidence intervals calculated with a linear regression model based on consumption/day of kilocalories as a dependent variable and predictors that include indicator variables for each socio-demographic correlate, Non-conservative overweight (Conservative overweight) and cross-product (interaction) terms between obese and indicator variables of the correlate. In addition, the linear regression model was adjusted by the following covariables: sex, age, physical activity, household size, food security, wealth index, ethnicity, education of the head, area and region. The complex sampling survey design was used in all multivariate regression models.

${ }^{\ddagger}$ In men $\geq 90 \mathrm{~cm}$, in women $\geq 80 \mathrm{~cm}$.

$\S$ The rural category included suburban population centres close to small cities, towns in rural areas distant from small towns and places dispersed or very distant from rural towns.

an isolated event that occurs outside the socio-economic and cultural context of the subjects. Furthermore, public policy can provide proper guidance on multiple levels ${ }^{(43)}$. The evidence presented herein, based on data on protein and energy intake from the 2015 ENSIN, will help institutions that are responsible for improving diets and nutrition ${ }^{(14)}$ to not only review and modify nutritional goals but also sustain them, as suggested by the Dietary Guidelines for Americans ${ }^{(9)}$. Incorporating sustainability in a possible update of the RIEN and the Food-based Dietary Guidelines (GABAS in 
Spanish) ${ }^{(44)}$ may also improve food security in the country ${ }^{(9,45)}$. Future modifications could include conscious eating as promoted by Canadian dietary guidelines ${ }^{(46)}$ and standardising recommendations in $\mathrm{g} / \mathrm{kg}$ per $\mathrm{d}^{(33)}$. Protein intake limits and the sources of protein can also be adapted, given that red meat and eggs can play a protective role in iron deficiency anemia, thereby reducing its prevalence in $\mathrm{Colombia}^{(47)}$. By having identified the age at which the current and adequate weight of the subjects began to deviate from each other, dietary and nutritional education as well as other multi-sector dietary interventions can be better targeted before excess weight develops. Various actions need to be taken to prevent pseudoscience from replacing food and nutrition education, such as compelling messages and actions regarding how long a diet needs to be followed before harm or benefits result, the complexity of interactions among different levels of risk factors and differences in individual and population interventions carried out in particular cultural contexts. Lastly, the data on the prevalence of protein intake deficiency reported in the 2005 ENSIN should be reviewed to take into account habitual or long-term consumption ${ }^{(13)}$.

\section{Strengths and limitations of the study}

The primary limitation of the present study was the inability to determine causal associations due to the cross-sectional design of the ENSIN. Another limitation was that the present study reported current intake rather than usual or long-term intake, given the use of the $24 \mathrm{HR}$ method. Sources of protein could also not be determined (animal or vegetable). Nevertheless, this analysis also has its strengths. The data were taken from a nationally representative survey that estimated energy and protein intake based on a 24HR that was administered by welltrained nutritionists. Furthermore, the $24 \mathrm{HR}$ was translated into nutrients based on the best food composition database available in Colombia.

\section{Supplementary material}

The supplementary material for this article can be found at https://doi.org/10.1017/jns.2021.2.

\section{Acknowledgements}

All the data analyzed during this study are available, they are publicly accessible through a reasoned request to the Ministry of Health and Social Protection of Colombia.

This investigation did not receive any specific subsidy from any funding agency, commercial sector or non-profit organisation.

M. P. Z. is a researcher of the dietary consumption component at ENSIN-2015. O. F. H. and M. P. Z. co-designed the study, co-prepared the databases and co-performed the statistical analyses. O. F. H., M. P. Z. and E. M. G. interpreted the results and prepared, wrote and reviewed the submitted final draft of the manuscript. All authors reviewed the manuscript and approved the final version.
The authors declare that they have no real or potential conflicts.

\section{References}

1. Flórez CE (2000) Las Transformaciones Sociedemográficas en Colombia Durante el Siglo XX. Bogotá, DC: Tercer Mundo Editores.

2. Kasper NM, Herrán OF \& Villamor E (2013) Obesity prevalence in Colombian adults is increasing fastest in lower socio-economic status groups and urban residents: results from two nationally representative surveys. Public Health Nutr 17, 2398-2406.

3. Herrán OF, Patiño GA \& DelCastillo SE (2016) La transición alimentaria y el exceso de peso en adultos evaluados con base en la Encuesta de la Situación Nutricional en Colombia, 2010 (The food transition and excess weight in adults evaluated based on the Survey of the Nutritional Situation in Colombia, 2010). Biomédica 36, 109-120.

4. Ocampo PR, Prada GE \& Herrán OF (2014) Patrones de consumo alimentario y exceso de peso infantil; encuesta de la situación nutricional en Colombia, 2010 (Food consumption patterns and child excess weight; survey of the nutritional situation in Colombia, 2010). Rev Chil Nutr 41, 351-359.

5. Herrán OF, Álvarez DC \& Quintero-Lesmes DC (2020) Dietary patterns and breast cancer in Colombia: an ecological study. Int Health 12, 317-324.

6. Turner C, Kalamatianou S, Drewnowski A, et al. (2020) Food environment research in low- and middle-income countries: a systematic scoping review. Adv Nutr 11, 387-397.

7. ICBF, ENSIN-2015 (2020) Resultados-Infografía. https://www. icbf.gov.co/sites/default/files/infografia_situacion_nutricional_18_ a_64_anos.pdf (accessed July 2020).

8. Herrán OF, Villamor E \& Quintero-Lesmes DC (2019) Adherence to a snacking dietary pattern is decreasing in Colombia among the youngest and the wealthiest: results of two representative national surveys. BMC Public Health 19, 1702.

9. Blackstone NT, El-Abbadi NH, McCabe MS, et al. (2018) Linking sustainability to the healthy eating patterns of the dietary guidelines for Americans: a modelling study. Lancet Planet Health 2, e344-e352.

10. Gaona-Pineda EB, Mejía-Rodríguez F, Cuevas-Nasu L, et al. (2018) Dietary intake and adequacy of energy and nutrients in Mexican adolescents: results from Ensanut 2012. Salud Publica Mex 60, 404-413.

11. De la Cruz-Góngora V, Martínez-Tapia B, Cuevas-Nasu L, et al. (2017) Dietary intake and adequacy of energy and nutrients in Mexican older adults: results from two National Health and Nutrition Surveys. Salud Publica Mex 59, 285-298.

12. Shan Z, Rehm CD, Rogers G, et al. (2019) Trends in dietary carbohydrate, protein, and fat intake and diet quality among US adults, 1999-2016. JAMA 322, 1178-1187.

13. Profamilia, Instituto Nacional de Salud, Universidad de Antioquia, OPS, Instituto Colombiano de Bienestar Familiar (2006). Encuesta Nacional de la Situación Nutricional de Colombia, 2005 (National Survey of the Nutritional Situation of Colombia, 2005). http://www. icbf.gov.co/portal/page/portal/PortalICBF/NormatividadGestion/ ENSIN1/ENSIN2005/LIBRO_2005.pdf (accessed May 2020).

14. Ministerio de Salud y Protección Social. Recomendaciones de ingesta de energía y nutrientes (RIEN) para la población Colombiana (Recommendations of energy and nutrient intake (RIEN) for the Colombian population). https://www.minsalud. gov.co/sites/rid/Lists/BibliotecaDigital/RIDE/VS/PP/SNA/ rien-documento-tecnico.pdf (accessed May 2020).

15. Minsalud ICBF (2018) Metodología ENSIN-2015 (ENSIN-2015 methodology). https://www.minsalud.gov.co/sites/rid/Lists/Biblioteca Digital/RIDE/VS/ED/GCFI/documento-metodologico-ensin-2015. pdf (accessed May 2020).

16. Blanton CA, Moshfegh AJ, Baer DJ, et al. (2006) The USDA automated multiple-pass method accurately estimates group total energy and nutrient intake. J Nutr 136, 2594-2599. 
17. Hodkinson HM (1972) Evaluation of a mental test score for assessment of mental impairment in the elderly. Age Ageing 1, 233-238.

18. De Onis M \& Lobstein T (2010) Defining obesity risk status in the general childhood population: Which cut-offs should we use? Int $J$ Pediatr Obes 5, 458-460.

19. Ministerio de Salud, Colombia, ICBF, Protección Social, Instituto Nacional de Salud (2020) Encuesta Nacional de la Situación Nutricional-ENSIN, 2015: Metodología. (National Survey of the Nutritional Situation-ENSIN, 2015: Methodology). https://www. icbf.gov.co/bienestar/nutricion/encuesta-nacional-situacion-nutricional\# ensin3 (accessed December 2020).

20. FAO (2001) Human energy requirements. http://www.fao.org/3/ a-y5686e.pdf (accessed June 2019).

21. Camargo DM \& Orozco LC (2013) Factores asociados a la disponibilidad y uso de medios electrónicos en niños desde pre-escolar hasta $4^{\circ}$ grado (Associated factors to availability and use of electronic media in children from preschool to 4th grade). Biomédica 33, 175-185.

22. Camargo DM, Santisteban S, Paredes E, et al. (2015) Confiabilidad de un cuestionario para medir la actividad física y los comportamientos sedentarios en niños desde preescolar hasta cuarto grado de primaria. Biomédica 35, 347-356.

23. CDC (2012) Youth Risk Behavior Surveillance System (YRBSS). https://www.cdc.gov/healthyyouth/data/yrbs/index.htm (accessed January 2020).

24. Craig CL, Marshall AL, Sjöström M, et al. (2003) International physical activity questionnaire: 12-country reliability and validity. Med $S_{c i}$ Sports Exerc 35, 1381-1395.

25. FAO (2012) Escala Latinoamericana y Caribeña de Seguridad Alimentaria (ELCSA) - Manual de uso y aplicación (Latin American and Caribbean Food Security Scale (ELCSA) - Use and application manual). http://www.fao.org/3/a-i3065s.pdf (accessed January 2019).

26. Rutstein SO (2008) The DHS Wealth Index: approaches for rural and urban areas. Demographic and Health Research 60. http:// www.popline.org/node/209748 (accessed February 2018).

27. StataCorp (2015) Stata Statistical Software: Release 14. College Station, TX: StataCorp LP.

28. Asociación Médica Mundial (2015) Declaración de Helsinki Principios éticos para las investigaciones médicas en seres humanos (Declaration of Helsinki - Ethical principles for medical research in humans). https://www.wma.net/es/policies-post/declaraciondehelsinki-de-la-amm-principios-eticos-para-las-investigaciones-medicas-en-seres-humanos/ (accessed November 2018).

29. Ministerio de Salud (Colombia) (1993) Resolución Numero 8430 de 1993 (Resolution number 8430 of 1993). https://www.minsalud. gov.co/sites/rid/Lists/BibliotecaDigital/RIDE/DE/DIJ/RESOLU CION-8430-DE-1993.PDF (accessed July 2020).

30. Wu G (2016) Dietary protein intake and human health. Food Funct 7, 1251-1265.

31. Tucker KL (2007) Assessment of usual dietary intake in population studies of gene-diet interaction. Nutr Metab Cardiovasc Dis 17, 74-81.
32. National Academy of Medicine (2005) Dietary Reference Intakes for Energy, Carbohydrate, Fiber, Fat, Fatty Acids, Cholesterol, Protein, and Amino Acids (Macronutrients). National Academies Press. https:// www.nap.edu/catalog/10490/dietary-reference-intakes-for-energycarbohydrate-fiber-fat-fatty-acids-cholesterol-protein-and-aminoacids (accessed November 2018).

33. Fulgoni VL (2008) Current protein intake in America: analysis of the National Health and Nutrition Examination Survey, 2003-2004. Am J Clin Nutr 87, 1554S-1557S.

34. Hoy MK, Clemens JC \& Moshfegh A. Protein Intake of Adults. What We Eat in America, NHANES 2015-2016. https://www. ars.usda.gov/ARSUserFiles/80400530/pdf/DBrief/29_Protein_ Intake_of_Adults_1516.pdf (accessed December 2020).

35. Song M, Fung TT, Hu FB, et al. (2016) Association of animal and plant protein intake with all-cause and cause-specific mortality. $J A M A$ 176, 1453-1463.

36. Willett W (2013) Nutritional Epidemiology, 3rd edition. New York: Oxford University Press.

37. Pagona L, Sven S, Marie L, et al. (2012) Low carbohydrate-high protein diet and incidence of cardiovascular diseases in Swedish women: prospective cohort study. $\mathrm{Br}$ Med J 344, e4026.

38. Yang SY, Kim YS, Lee JE, et al. (2016) Dietary protein and fat intake in relation to risk of colorectal adenoma in Korean. Medicine 95, e5453.

39. Shan R, Duan W, Liu L, et al. (2018) Low-carbohydrate, highprotein, high-fat diets rich in livestock, poultry and their products predict impending risk of type 2 diabetes in Chinese individuals that exceed their calculated caloric requirement. Nutrients 12, 77.

40. Farhadnejad H, Asghari G, Emamat H, et al. (2019) Low-carbohydrate high-protein diet is associated with increased risk of incident chronic kidney diseases among Tehranian adults. $J$ Ren Nutr 29, 343-349.

41. Ko G J, Obi Y, Tortorici AR, et al. (2017) Dietary protein intake and chronic kidney disease. Curr Opin Clin Nutr Metab Care 20, 77-85.

42. Willett W, Johan Rockström J, Brent Loken B, et al. (2019) Food in the Anthropocene: the EAT-Lancet Commission on healthy diets from sustainable food systems. The Lancet 393, 447-492.

43. Reich MR \& Balarajan Y (2014) Political economy analysis for nutrition policy. Lancet Glob Health 2, e681-e682.

43. ICBF (2018) Guías alimentarias basadas en alimentos para la población colombiana mayor de 2 años (GABAS) (Food-based dietary guidelines for the Colombian population older than 2 years (GABAS)) (https://www.icbf.gov.co/programas-y-estrategias/ nutricion/guias-alimentarias-basadas-en-alimentos-para-la-poblacion) (accessed September 2020).

45. Milner J \& Green R (2018) Sustainable diets are context specific but are they realistic? Lancet Planet Health 2, e425-e426.

46. Webster P (2019) Canada's updated food guide promotes mindful eating Lancet 393. http://www.thelancet.com/article/ S0140673619302028/fulltext (accessed May 2020).

47. Herran OF, Bermúdez JN \& Del Pilar Zea M (2020) Red meat and egg intake and serum ferritin concentrations in Colombian children: results of a population survey, ENSIN-2015. J Nutr Sci 9, 1-11. 